\title{
Рынок Private Equity в России 59
}

\author{
Кокорев Д.А. ${ }^{60}$
}

В данной статье представлен обзор ключевых докладов и выступлений на российском конгрессе Private Equity, прошедшем 29 октяборя 2009 года и организованном агентством CВоnd, журналом Russian Private Equity и Группой ММВБ.

JEL: G10; G20; G24

Ключевые слова: фонды прямых инвестищий, венчурные фонды

29 октября состоялся Российский конгресс Private Equity. Форум был организован агентством Cbonds, журналом Russian Private Equity и Группой ММВБ. Данная конференция собрала практически всех профессионалов отрасли прямого инвестирования, работающих в России.

Несмотря на молодость отрасли прямого инвестирования (первая сделка была зафиксирована только в 1946 году, а рассвет отрасли прямых инвестиций начался в 70-е годы XX века), на текущий момент данный рынок измеряется в триллионах долларов. Об этом в одном из первых выступлений рассказал Кирилл Самсонов, издатель журнала Russian Private Equity. Российский рынок, по оценкам господина Самсонова, составляет около 6 млрд долларов, а фонды имеют около 4 млрд свободных для инвестирования средств. Для сравнения - в Индии объем рынка составляет 60 млрд долларов, а в Китае 100 млрд долл. Но при этом стоит отметить, что в том же Китае около 90\% инвесторов в фонды прямых инвестиций (далее - ФПИ) - местные игроки. В России же доля отечественных инвесторов в ФПИ существенно меньше, соответственно у нас роста отрасли можно ожидать тогда, когда локальные игроки начнут вкладывать средства в ФПИ.

Описание российского рынка прямых инвестиций продолжил Алексей Парфенов, управляющий партнер, NRG. Алексей Парфенов обратил внимание на то, что ввиду фазы зарождения данной отрасли в нашей стране она на текущий момент практически никак не регулируется. Все сделки уникальны и нестандартны, и практически все они осуществляются в англосаксонской системе права. Если говорить о структуре рынка, то она выглядит следующим образом:

1. Лидер рынка - фонд ВVCР, который работает на рынке с 1994 года.

2. Кэптивные фонды (например, «ОНЕКСИМ» Михаила Прохорова или «Интеррос» Владимира Потанина).

3. Полукэптивные фонды, к которым можно отнести фонды «Тройки Диалог», «Ренессанс Капитала», «Альф-Групп» и т.п.

4. Независимые фонды, такие как NRG, MINT, Svarog.

5. И дочки западных фондов, наиболее ярким представителем которых является фонд Russia Capital Partners.

Представитель именно данного фонда (Russia Capital Partners), Юрий Машинцев, продолжил тему специфики функционирования ФПИ в России, акцентировав внимание на механизмах управления портфельной компанией, которые использую фонды. Так, Юрий выделил три основных стратегии работы фондов:

\footnotetext{
59 Данная статья написана по материалам 1-го Российского конгресса Private Equity. Автор выражает благодарность агентству Cbonds и лично его генеральному директору Сергею Лялину за предоставленную возможность участия в данном мероприятии.

${ }^{60}$ Аспирант факультета экономики, кафедра экономики и финансов фирмы ГУ ВШЭ.
} 
1. Пассажир - минимальное участие в деятельности компании, которое ограничивается участием в совете директоров и финансовым контролем компании.

2. Создатель - в противовес первому варианту, наиболее активная стратегия работы фонда, которая зачастую подразумевает создание бизнеса с нуля, подбор команды менеджмента и постоянный полный контроль над компанией.

3. Партнер - активное участие в деятельности портфельной компании, но при этом данное участие происходит в сферах компетенции фонда: консультации, международная экспертиза бизнеса, постановка бюджетирования, привлечение финансов, участие в M\&A сделках и проч. Но при этом всегда надо понимать, что предприниматель будет по-настоящему воспринимать фонд как партнера только тогда, когда будет видеть, что он «впрягается» так же, как и он, и пашет от рассвета до заката.

Также Юрий обозначил основные инструменты, с помощью которых фонды могут максимально эффективно контролировать компанию и взаимодействовать с нею. К ним относятся кадровая политика, участие в разработке стратегии, финансовое бюджетирование, использование в компании best practices, а также ввод вспомогательных систем (KPI, ERP и риск-менеджмента). Правда, использовать данные инструменты нужно очень аккуратно, тщательно учитывая специфику бизнеса (например, KPI для бизнеса с высокой творческой составляющей могут быть опасны).

Наглядные результаты опроса предпринимателей были представлены в докладе Евгения Самойлова, генерального директора компании «Бейкер Тилли Русаудит». Доклад под названием «Как менеджмент компаний реального сектора воспринимает бизнес фондов прямых инвестиций» основывался на проведенном опросе 24 топ-менеджеров российских компаний, из них $30 \%$ опрошенных - с опытом общения с ФПИ. Было задано всего несколько вопросов, но ответы на них являются довольно показательными. Так, на вопрос об основных целях деятельности ФПИ 57\% тех менеджеров, которые не общались с фондами, ответили, что считают, что ФПИ создаются для инвестиций в реальный сектор. При этом ни один из топ-менеджеров данной категории не считает, что цель фонда получение прибыли за счет разницы цены покупки и цены продажи компании. На вопрос о том, как фонды оценивают привлекательность потенциальной целевой компании, 43\% респондентов заявили, что оценка осуществляется по финансовым показателям (IRR, EBITDA и т.п.), $14 \%$ - что по перспективам роста, остальные $43 \%$ не знают ответа на данный вопрос. Таким образом, можно заключить, что российское предпринимательское сообщество пока что очень слабо представляет, зачем нужны ФПИ, какие цели они преследуют и как подходят к оценке бизнеса и его перспектив.

Помимо выступлений профессиональных участников рынка ФПИ на конференции также выступили два представителя предпринимательского сообщества: Александр Глушков, президент сети салонов красоты «МОНЭ», и Олег Тиньков, председатель совета директоров «Банка Тинькофф Кредитные Системы». Оба предпринимателя очень позитивно оценили свой опыт работы с ФПИ, а также преимущества для предпринимателя от такого взаимодействия. К таковым они отнесли независимую стороннюю оценку бизнеса, развитие системы корпоративного управления, привнесение в бизнес опыта, полученного ФПИ в других портфельных компаниях, повышенный уровень аналитики бизнеса. Но, при этом оба предпринимателя отметили, что появляется и ряд ограничений на ведение бизнеса: зачастую фонд пытается активно участвовать и в операционной стороне деятельности компании (которую предприниматели считают исключительно своей вотчиной). Важно и то, что фонд зачастую имеет краткосрочные цели (3-5 лет), что может влиять на стратегию бизнеса, и это также не всегда совпадает с видением развития бизнеса предпринимателями.

Исходя из своего опыта, предприниматели дают следующие советы: начиная взаимодействовать с фондом, надо очень тщательно подходить к его выбору, как бы примеряя его под себя. При этом к ФПИ стоит относиться как к топ-менеджеру компании, который тоже должен участвовать в бизнесе. Но и не стоит при этом рассчитывать на чудо - 
с появлением в числе собственников ФПИ необходимость брать ответственность за ключевые решения на себя у предпринимателей никуда не исчезнет. Так же важно учитывать цели фонда (получить максимальную прибыль на разнице цены покупки и продажи), и не стоит жадничать при входе фонда в бизнес - лучше найти тот фонд, который больше подходит компании по своей стратегии и уступить ему долю дешевле; чем продать дорого долю фонду, с которым потом будет некомфортно работать на протяжении нескольких лет. В конечном итоге как только фонд войдет в бизнес, ваши цели с ним станут одинаковыми: максимизация капитализации бизнеса. Так, по словам Олега Тинькова, нужна персональная совместимость, никакие соглашения акционеров не помогут получить полные гарантии для обеих сторон; более того, использование данных соглашений с целью давления друг на друга - прямой путь к уничтожению стоимости бизнеса.

В ходе панельных дискуссий основной акцент ставился на влияние кризиса на работу ФПИ в России. Так, практически все управляющие отметили, что стало поступать существенно больше заявок на инвестирование, но при этом фонды, в свою очередь, сократили инвестиции в новые компании. Большинство из них с поиска проектов переключилось на активное управление текущими портфельными компаниями. При этом, несмотря на то что стали появляться новости о создании новых фондов, нацеленных на инвестиции в Россию, по мнению Олега Царькова, управляющего партнера Svarog Capital, об определении тренда дальнейшего развития рынка можно будет говорить только после I квартала 2010 года. Также все участники дискуссии сошлись на мнении о том, что необходимо прилагать усилия для популяризации ФПИ в России, причем как среди бизнеса, так и среди потенциальных инвесторов.

Подводя итоги форума, один из его организаторов, Сергей Лялин, генеральный директор Cbonds, отметил, что мероприятие оказалось очень популярным (посещение почти в 2 раза превысило первоначальные прогнозы) и в целом есть признаки того, что в будущем можно ожидать роста интереса к отрасли прямого инвестирования в России. 